\title{
Index of Names
}

Adams, R.M. 230

Archimedes 77

Aristotle 109, 174f., 199, 206, 216-222, 305, 307

Armstrong, D. 187188

Arnauld, A. 24, 28

Ayer, A.J. 298

Baker, L. R. 156-157

Barlow, H. 213

Bayne, T. 161, 182184, 186, 190-191, 195

Bennett, M.K. 254, 257

Berkeley, G. 111, 112, 123, 124, 290

Block, N. 274, 276, 280, 281, 297

Bogart, H. 255

Bramhall, J. 232-233

Brentano, F. 174f., 275

Brosnan, S. 107

Burge, T. 59f., 282283, 296

Butler, J. 111, 112, 123, 124

Campbell, J. 57-63

Chalmers, D.J. 18

Changeux, J-P. 107

Chomsky, N. 209, 271, 273, 298

Churchland, P. 281

Clark, A. 18

Crane, T. 275-276

Crick, F. 213
Damasio, A. 130f., 213

Davidson, D. 264, 269f., 281

Dennett, D. 90, 152, 256-257, 269, 270f., 274, 281

Descartes, R. 24-25, 27-28, 45, 57-58, 66-68, 74, 111f., 165, 199, 201-211, $215,217,223,279$

Edelman, G. 213

Egan, F. 259

Elizabeth (Princess of Bohemia) 208

Feigl, H. 283

Field, H. 264

Fine, K. 78f., 79f., 83f., 86f., 88f., 89

Fodor, J. 88f., 92, 258-259, 262, 264, 292, 308, 310

Frankfurt, H. 240, 242-247, 249-250, $251 \mathrm{f}$.

Frith, C. 212, 253254, 258, 262, $317 f$.

Gassendi, P. 66-67

Gazzaniga, M. 213

Geulincx, A. 208

Giere, R. 260, 262

God 24, 46, 132, 139140, 209, 286

Godfrey-Smith, P. 261

Hacker, P.M.S. 254, 257-258
Hacking, I. 301, 303, 319, 322f., 323f., 324

Hobbes, T. 225f., 226-229, 231, 232237, 239, 248, 251f.

Hudson, H. 55

Hume, D. 73-74, 107, 180f., 204, 229, 232, $238,239,248,275$, 293, 300

Jackson, F. 25, 187, 189, 282

James, H. 115

Johnston, M. 45f., 143-159, 161, 182186, 190-191

Kant, I. 77, 144, 147f., 211, 305

Kim, J. 281

Kirk, R. 28, 294

Köhler, W., 322, 324

Kripke, S. 25-26

Law, (Bishop) 112, 124

Lewis, D. 8f., 10f., 78f., 83, 88f., 192193, 196, 267

Libet, B. 212

Lichtenberg, G. 58, 59-63, 72

Locke, J. 25, 44, 5152, 54, 93-94, 111141, 144f., 164, 165 , 172-173, 176, 179, 231, 240-242, 281, 299 
Macbeth 145

Mackie, J.L. 116

Malcolm, N. 268, $273 f$.

Malebranche, N. 208

McDowell, J. 301$308,310,312,315$, 319-321, 323-327

McGinn, C. 271, 273, 285, 296, 299

Meany, M. 103

Mellor, D.H. 187-188

Mencius 109

Montero, B. 283-284

Moore, G.E. 61-66, 68,311

Mulhall, S. 254-256, $270 f$.

Mumford, S. 188, $231 \mathrm{f}$.

Nagel, T. 25, 32, 271, 273-276, 298f.

Neleus 222

Nestor (example) 127

Newton, I. 210

Noe, A. 282-283

Nolan, D. 10-11

Ockham, (W. of) 29

Olson, E. 77f., 93f., $161,176,177-181$

Papineau, D. 21, 3036, 292f.

Parfit, D. 39-56, 77f., 126, 140, 145f., 177, 179f., 301, 303, 319-326
Pargetter, R. 187, 189

Paul (Apostle) 150

Pauli, W. 10-11

Peacocke, C. 58f., 165-166, 168, 174f.

Perry, J. 146

Plato 11, 109, 216, 218

Pollock, J. 255, 258

Popper, K. 273

Prior, A.N. 187, 189

Putnam, H. 282-283, 297

Pythagoras 218

Quine, W.V.O. 274, 308, $310 f$.

Reid, T. 112, 123, 124, 139

Robinson, H. 280

Rödl, S. 301-302, 311, 317-320

Rosenthal, D. 281

Rumfitt, I. 268

Rupert, R. 3-4, 7-8, 19

Rutherford, E. 260, 266

Ryle, G. 29, 70-71

Scanlon, T.M. 229230

Schechtman, M. 131

Searle, J. 157f., 206, 263f., 264f., 273, $275,281,292-293$

Sellars, W. 25, 79-80, 91, 308f.

Shoemaker, S. 39, 40, 93f., $121 \mathrm{f}$.
Smart, J.J.C. 21, 2830,36

Snowdon, P. 45f., 93f., 176

Socrates 144, 151

Strawson, G. 56f, 177f., 186, 197f., 226, 227f., 238, 264f., 281

Strawson, P. 29, $223 f$.

Suarez, F. 233, 234f., 235

Suppes, P. 259-261

Theophrastus 222

Tomasello, M. 301, 315-327

Unger, P. 39f., 84f., 85f., 165, 166

Van Frassen, B. 259260

Vygotsky, L. 301-327

Weisberg, M. 261, $270 f$.

Williams, B. 227, 301

Williams, M. 307, 308, 309-310, 313, 326

Willis, B. 192

Wittgenstein, L. 29, 254, 256-258, 273, 299, 301, 303-309, 310f., 311, 312, 317f., 322, 323f., $327 f$. 
Questions relating to the mind, to the self and to personhood have been in the forefront of philosophical enquiry throughout the history of the subject, and, as will be evident from this volume, is as lively and contested an area of investigation in the twenty-first century, as it was in the days of the ancient Greeks.

The topic is not only lively: as the papers collected here amply demonstrate it covers a wide range of issues: consciousness itself, the mind and its relation to the body, the self, the nature of the human person, personal identity, the relation of the mind to morality, the existence of group minds and the implications of what we think about the mind for education. These and other topics are vigorously investigated by a distinguished group of leading figures in current philosophy of mind.

\section{Contributors}

Mark Sprevak, Paul Snowdon, Eric Olson, Lucy O’Brien, Rory Madden, Patricia Churchland, Galen Strawson, Lynne Rudder Baker, Barry Dainton, P.M.S. Hacker, Thomas Pink, Tim Crane, Ted Honderich, David Bakhurst

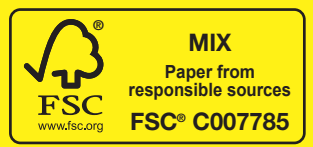

